\title{
Cationic Tungsten(VI) Penta-Methyl Complex: Synthesis, Characterization and its Application in Olefin Metathesis Reaction
}

\author{
Raju Dey ${ }^{1}$, Manoja K. Samantaray ${ }^{1}$, Emmanuel Callens' ${ }^{1}$ Ali Hamieh' ${ }^{1}$ Abdul-Hamid M. Emwas ${ }^{2}$, \\ Edy Abou-hamad', Santosh Kavitake ${ }^{1}$ and Jean-Marie Basset ${ }^{1}$ * \\ ${ }^{1}$ King Abdullah University of Science \& Technology, KAUST Catalysis Center (KCC), Thuwal 23955-6900 - Saudi Arabia \\ 2 Imaging and Characterization Core Lab, King Abdullah University of Science and Technology (KAUST), Thuwal 23955-6900 - Saudi Arabia \\ e-mail: jeanmarie.basset@kaust.edu.sa \\ * Corresponding author
}

\begin{abstract}
Tungsten-hexa-methyl readily reacts with $B\left(C_{6} F_{5}\right)_{3}$ in dichloromethane and generates the corresponding well-defined cationic tungsten-penta-methyl complex which was identified precisely by ${ }^{1} \mathrm{H} N M R,{ }^{13} \mathrm{C} N M R,{ }^{1} \mathrm{H}_{-}{ }^{13} \mathrm{C} N M R$ correlation spectroscopy. Unlike $W M e_{6}$, this cationic complex has low energy barrier to form tungsten carbene intermediate, which was further supported by the fact that $W_{M} e_{6}$ alone has no activity in olefin metathesis reaction whereas the cationic complex shows catalytic activity for self-metathesis of 1-octene.
\end{abstract}

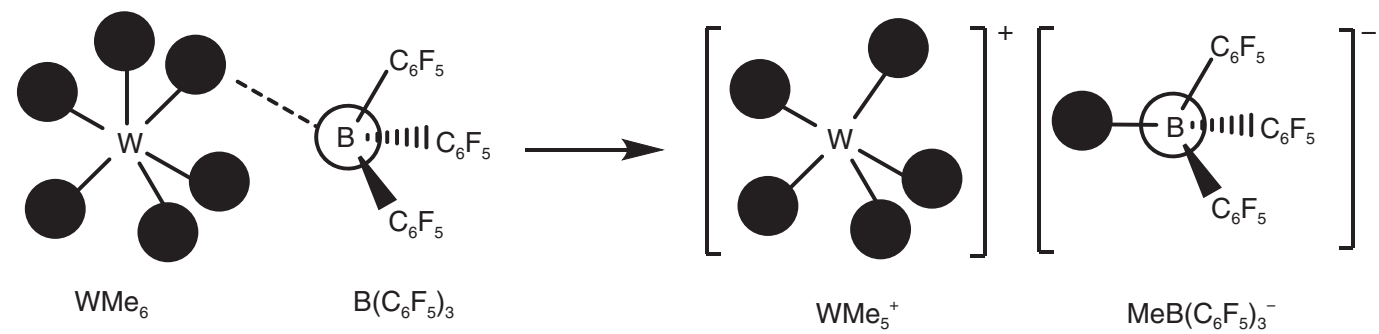

Résumé - Complexe pentaméthyle de tungstène(VI) cationique : synthèse, caractérisation et son application dans la réaction de métathèse des oléfines — L'hexaméthyle de tungstène réagit avec le $\mathrm{B}\left(\mathrm{C}_{6} \mathrm{~F}_{5}\right)_{3}$ dans du dichlorométhane et génère le complexe pentaméthyle de tungstène cationique bien défini qui a été précisément identifié par spectroscopie de corrélation ${ }^{1} \mathrm{H}$ RMN,${ }^{13} \mathrm{C} R M N$, ${ }^{1} \mathrm{H}_{-}{ }^{13} \mathrm{C} \mathrm{RMN}$. À la différence du $\mathrm{WMe}_{6}$, ce complexe cationique a une barrière énergétique faible pour former un intermédiaire de carbène tungstène, ce qui a été ultérieurement étayé par le fait que le $\mathrm{WMe}_{6}$ seul n'a pas d'activité dans la réaction de métathèse des oléfines, tandis que le complexe cationique montre une activité catalytique pour l'autométathèse d'1-octène. 


\section{INTRODUCTION}

In 1973, Shortlan and Wilkinson described the first report on Tungsten hexamethyl [1], [2-4]. After its synthesis, the structure was established in 1996 by Seppelt [5], [6, 7] and Kaupp [8]. The geometry was calculated by Demolliens et al. [9] and Kang et al. [10]. However, until 2015 and to our knowledge there was no report on the catalytic activity of this homoleptic complex. $\mathrm{WMe}_{6}$ is indeed difficult to prepare, extremely unstable, and very sensitive to even few ppm levels of oxygen or moisture. Handling this compound is challenging due to its explosive nature as reported by Shortlan and Wilkinson [1, 2], Galyer et al. [3], Galyer and Wilkinson [4]. In our previous communication, we demonstrated that grafting this unstable $\mathrm{WMe}_{6}$ to the silica surface by SOMC (Surface OrganoMetallic Chemistry) strategy and methodology at $-80^{\circ} \mathrm{C}$ can enhance its thermal stability due to the formation of the stable grafted complex, [ $\left.\equiv \mathrm{SiO}-\mathrm{W}(\mathrm{Me})_{5}\right]$ which proved to be a nice precursor of alkane metathesis catalysts via the formation of surface monopodal tungsten carbyne [11]. This carbyne is in equilibrium with a bis carbene upon addition of a donor ligand [12] (Scheme 1). Also, we demonstrated that $\mathrm{WMe}_{6}$ on silica-alumina shows relatively higher reactivity than on silica because of the formation of very reactive cationic intermediate [13]. Let us recall that Kress and Osborn were the first to report the synthesis of a cationic W-carbene very active in olefin metathesis [14]. Based on the above fact we speculate that in order to prepare more reactive catalysts in terms of reactivity and selectivity a higher electrophilicity on tungsten center is essential.

However, high oxidation state cationic complexes of tungsten are very rare, especially those which do not contain a coordinating ligand [15] and these complexes are expected to be more reactive than the corresponding neutral complexes [14]. Cationic tungsten complex containing one or more stabilizing ligands e.g. oxygen, nitrogen, or oxygen, nitrogen, phosphorous containing ligand, cyclopentadienyl ligand are relatively stable and are described in the literature [14, 16-20]. Very recently, Schowner et al. have reported the synthesis of first cationic tungsten-oxo-alkylidene-Nheterocyclic-carbene complexes where the cationic metal center was stabilized by N-heterocyclic carbene [20].

To the best of our knowledge, the only example for homoleptic cationic tungsten-alkyl complex was reported in the literature by Wilkinson et al. Even in this paper they mentioned the reaction of $\mathrm{WMe}_{6}$ with $\mathrm{AlCl}_{3}$ which would lead to the formation of $\mathrm{WMe}_{5}{ }^{+}$but without any proof [1-4].

\section{EXPERIMENTAL}

All experiments were carried out by using standard Schlenk and glovebox techniques under an inert nitrogen atmosphere. The syntheses and the treatments of the surface species were carried out using high-vacuum lines $\left(<10^{-5}\right.$ mbar) and glovebox techniques. Pentane was distilled from a $\mathrm{Na} / \mathrm{K}$ alloy under $\mathrm{N}_{2}$ and dichloromethane from $\mathrm{CaH}_{2}$. Both solvents were degassed through freezepump-thaw cycles. $\mathrm{SiO}_{2-700}$ was prepared by calcination at $300^{\circ} \mathrm{C}$ in the presence of air followed by dehydroxylation at $700^{\circ} \mathrm{C}$ under high vacuum $\left(<10^{-5}\right.$ mbar $)$ for $24 \mathrm{~h}$. It contained $0.5-0.7 \mathrm{OH}$ per $\mathrm{nm}^{2}$.

${ }^{1} \mathrm{H}$ NMR spectra were recorded at $600 \mathrm{MHz}$ in $\mathrm{CD}_{2} \mathrm{Cl}_{2}$ unless otherwise stated. Chemical shifts are reported in ppm with the solvent resonance $\left(\mathrm{CD}_{2} \mathrm{Cl}_{2}: 5.32 \mathrm{ppm}\right)$. Data are reported as follows: chemical shift, integration, and coupling constants $(\mathrm{Hz}) .{ }^{13} \mathrm{C}$ NMR were recorded at $150 \mathrm{MHz}$ in $\mathrm{CD}_{2} \mathrm{Cl}_{2}$ unless otherwise stated with complete proton decoupling. Chemical shifts are reported in ppm from solvent peak as the standard $\left(\mathrm{CD}_{2} \mathrm{Cl}_{2}: 53.84 \mathrm{ppm}\right)$.

\subsection{1-Octene Metathesis}

A mixture of catalytic species and dry 1-octene were mixed inside the glovebox. The ampoules were sealed under vacuum, kept at room temperature for $12 \mathrm{~h}$. At the end of the reaction, the ampoules were frozen under liquid nitrogen. Then, the catalytic run was quenched by addition of a fixed amount of $\mathrm{CH}_{2} \mathrm{Cl}_{2}$ and after filtration the resulting solution was analyzed by $\mathrm{GC}$ and $\mathrm{GC} / \mathrm{MS}$.

GC measurements were performed with an Agilent 7890 A Series (FID detection). Method for GC analyses: column HP-5; $30 \mathrm{~m}$ length $0.32 \mathrm{~mm}$ ID X $0.25 \mathrm{~mm}$ film thickness; flow rate: $1 \mathrm{~mL} . \mathrm{min}^{-1}(\mathrm{~N} 2)$; split ratio: $50 / 1$; inlet temperature: $250{ }^{\circ} \mathrm{C}$; detector temperature: $250{ }^{\circ} \mathrm{C}$; temperature program: $40{ }^{\circ} \mathrm{C}(3 \mathrm{~min}), 40-250{ }^{\circ} \mathrm{C}\left(12{ }^{\circ} \mathrm{C} \cdot \min ^{-1}\right), 250{ }^{\circ} \mathrm{C}$ (3 min), 250-300 ${ }^{\circ} \mathrm{C}\left(10{ }^{\circ} \mathrm{C} \cdot \mathrm{min}^{-1}\right), 300{ }^{\circ} \mathrm{C}(3 \mathrm{~min})$; $n$-decane retention time: $t R=9.6$.

\subsection{Preparation of Hexamethyltungsten, $\mathrm{WMe}_{6}$}

The molecular precursor $\mathrm{WMe}_{6}$ was prepared from $\mathrm{WCl}_{6}$ and $\left(\mathrm{CH}_{3}\right)_{2} \mathrm{Zn}$, following the literature procedure $[1,6]$. To a mixture of $\mathrm{WCl}_{6}(1.80 \mathrm{~g}, 4.5 \mathrm{mmol})$ in dichloromethane $(25 \mathrm{~mL})$ was added $\left(\mathrm{CH}_{3}\right)_{2} \mathrm{Zn}(13.6 \mathrm{mmol}, 1.0 \mathrm{M}$ in heptane $)$ at $-80{ }^{\circ} \mathrm{C}$, and after addition, the reaction mixture was warmed to $-35^{\circ} \mathrm{C}$ and stirred at this temperature for another $30 \mathrm{~min}$. After successive filtrations with pentane and removal of the solvent, the red solid corresponding to $\mathrm{WMe}_{6}$ was obtained $(0.16 \mathrm{~g}, 12 \%)$.

Caution! This $12 \mathrm{e}^{-}$compound is highly unstable and is prone to violent decomposition [1].

${ }^{1} \mathrm{H}$ NMR $\left(\mathrm{CD}_{2} \mathrm{Cl}_{2}, 600 \mathrm{MHz}\right): \delta(\mathrm{ppm}) 1.65(\mathrm{~s}, 18 \mathrm{H}$, $\left.\mathrm{WCH}_{3}\right) .{ }^{13} \mathrm{C} \mathrm{NMR}\left(\mathrm{CD}_{2} \mathrm{Cl}_{2}, 150 \mathrm{MHz}\right): \delta(\mathrm{ppm}) 82$ (s, 6C, J183 W- ${ }^{13} \mathrm{C}=47 \mathrm{~Hz}, \mathrm{WCH}_{3}$ ). HSQC (Heteronuclear Single Quantum Coherence) confirms the correlation between the ${ }^{1} \mathrm{H}$ and ${ }^{13} \mathrm{C}$ NMR signals. 


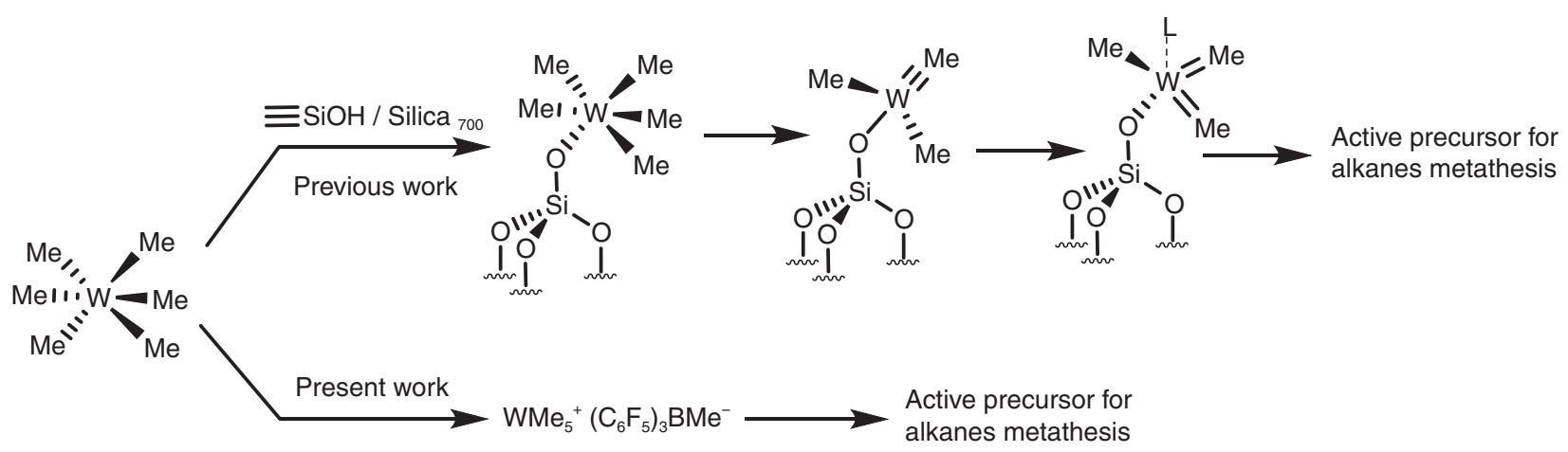

Scheme 1

Application of $\mathrm{WMe}_{6}$ in SOMC and in solution (present work).

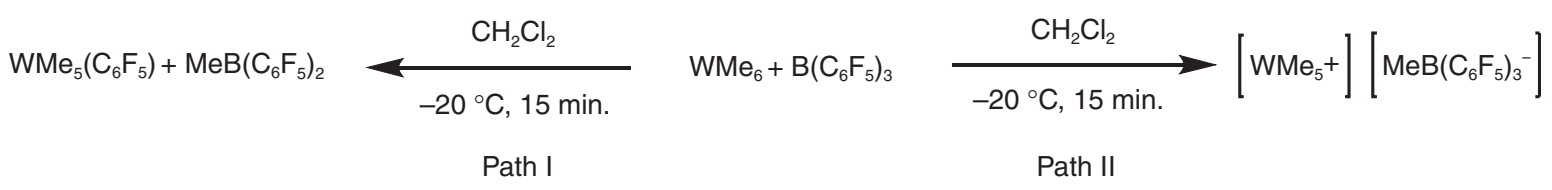

Scheme 2

Possible reaction between $\mathrm{WMe}_{6}$ and $\mathrm{B}\left(\mathrm{C}_{6} \mathrm{~F}_{5}\right)_{3}$.

The ${ }^{13} \mathrm{C}$-enriched $\mathrm{W}\left({ }^{13} \mathrm{CH}_{3}\right)_{6}$ was synthesised as described below: ${ }^{13} \mathrm{C}$-enriched $\left({ }^{13} \mathrm{CH}_{3}\right)_{2} \mathrm{Zn}$ was prepared from a suspension of ${ }^{13} \mathrm{CH}_{3} \mathrm{Li}$ and $\mathrm{ZnCl}_{2}(2 / 1)$, with subsequent synthetic steps being analogous to those provided above.

\subsection{Preparation of $\left[\mathrm{WMe}_{5}{ }^{+} \mathrm{B}\left(\mathrm{C}_{6} \mathrm{~F}_{5}\right)_{3} \mathrm{Me}^{-}\right]$}

A cold solution $\left(-20^{\circ} \mathrm{C}\right)$ of $\mathrm{B}\left(\mathrm{C}_{6} \mathrm{~F}_{5}\right)_{3}(100 \mathrm{mg})$ in dichloromethane was added drop wise to the cold $\left(-20^{\circ} \mathrm{C}\right)$ solution of hexamethyltungsten $(55 \mathrm{mg}, 1$ equiv. with respect to $\mathrm{B}$ $\left.\left(\mathrm{C}_{6} \mathrm{~F}_{5}\right)_{3}\right)$ in dichloromethane. The mixture was stirred for $15 \mathrm{~min}$ at $-20^{\circ} \mathrm{C}$. Color of the solution intensified to reddish indicating the formation of ionic complex. At temperature below $-60{ }^{\circ} \mathrm{C}$, this ionic complex is precipitated out from the solution however this $10 \mathrm{e}^{-}$compound is highly unstable and decompose into black tungsten power while drying.

Caution! This $10 \mathrm{e}^{-}$compound is highly unstable and is prone to violent decomposition.

${ }^{1} \mathrm{H}-\mathrm{NMR}(600 \mathrm{MHz}) \delta(\mathrm{ppm}) \quad 0.5\left(\mathrm{~s}, 3 \mathrm{H}, \mathrm{BCH}_{3}\right), 2.7$ $\left(\mathrm{s}, 15 \mathrm{H}, \quad \mathrm{WCH}_{3}\right) \cdot{ }^{13} \mathrm{C} \operatorname{NMR}(150 \mathrm{MHz}) \delta(\mathrm{ppm}) 10.8$ (s, $\left.1 \mathrm{C}, \mathrm{BCH}_{3}\right), 103.2\left(\mathrm{~s}, 5 \mathrm{C}, \mathrm{WCH}_{3}\right)$.

\subsection{Grafting of $\left[\mathrm{WMe}_{5}{ }^{+} \mathrm{B}\left(\mathrm{C}_{6} \mathrm{~F}_{5}\right)_{3} \mathrm{Me}^{-}\right]$on Silica ${ }_{700}$}

A solution of $\left[\mathrm{WMe}_{5}{ }^{+} \mathrm{B}\left(\mathrm{C}_{6} \mathrm{~F}_{5}\right)_{3} \mathrm{Me}^{-}\right](85 \mathrm{mg}, 1.2$ equiv. with respect to $\mathrm{WMe}_{6}$ and with respect to the amount of surface-accessible silanols) in dichlomethane $(15 \mathrm{~mL})$ was mixed with silica $\left(\mathrm{SiO}_{2-700} ; 1.0 \mathrm{~g}\right)$ at $-50{ }^{\circ} \mathrm{C}$ for one hour, allowed to warm to $-30{ }^{\circ} \mathrm{C}$, and then stirred for an additional $2 \mathrm{~h}$. At the end of the reaction, the resulting brown solid was washed with pentane $(3 \times 20 \mathrm{~mL})$ and dried under dynamic vacuum $(1 \mathrm{mPa}, 1 \mathrm{~h})$.

${ }^{1} \mathrm{H}$ solid-state NMR(400 MHz): $\delta(\mathrm{ppm}) 2.0\left(\mathrm{~b}, \mathrm{~W}-\mathrm{CH}_{3}\right)$. ${ }^{13} \mathrm{C}$ CP/MAS solid-state NMR(100 MHz): $\delta(\mathrm{ppm}) 83.0$ (W-CH $\mathrm{CH}_{3}$, 46.0(W-CH$)$ [11].

\section{RESULTS AND DISCUSSION}

As a part of our continuing program to explore the novel applications of tungsten hexamethyl, we report here the synthesis of the cationic tungsten-penta-methyl complex $\left[\mathrm{WMe}_{5}\right]^{+}\left[\mathrm{MeB}\left(\mathrm{C}_{6} \mathrm{~F}_{5}\right)_{3}{ }^{-}\right]$, starting from $\mathrm{WMe}_{6}$ and its application in olefin metathesis. The experimental procedure is very simple. Simple mixing of bulky and noncoordinating Lewis acid, $\mathrm{B}\left(\mathrm{C}_{6} \mathrm{~F}_{5}\right)_{3}$ with $\mathrm{WMe}_{6}$ at very low temperature $\left(-20{ }^{\circ} \mathrm{C}\right)$ generates quantitatively the cationic tungsten-penta-methyl complex $\left[\mathrm{WMe}_{5}\right]^{+}\left[\mathrm{MeB}\left(\mathrm{C}_{6} \mathrm{~F}_{5}\right)_{3}{ }^{-}\right]$.

In a preliminary study, we tried to synthesise $\mathrm{WMe}_{5}{ }^{+}$ according to literature reference using $\mathrm{AlCl}_{3}$ as a de-methylating reagent but after several attempts we were unable to get the desired product [1-4]. Subsequently, we switched to tris(pentafluorophenyl)-boron which is known to form a 


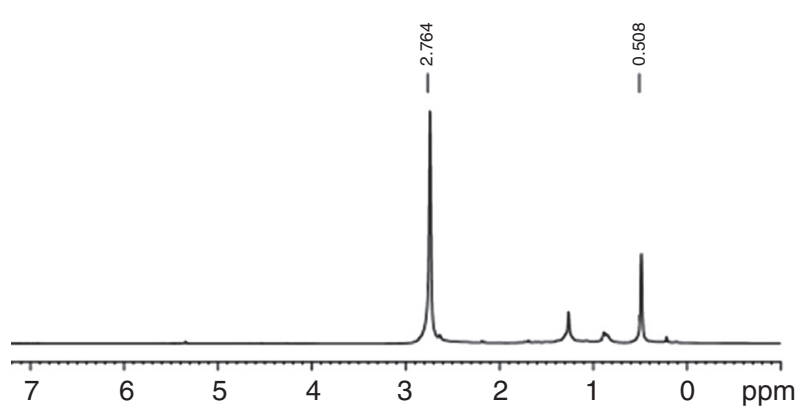

a)

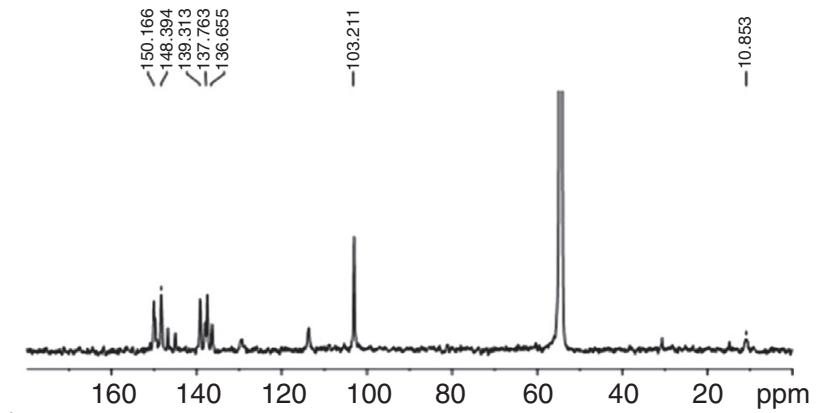

b)

Figure 1

a) ${ }^{1} \mathrm{H}$ NMR spectra, b) ${ }^{13} \mathrm{C}$ NMR spectra of $\left[\mathrm{WMe}_{5}\right]^{+}\left[\mathrm{MeB}\left(\mathrm{C}_{6} \mathrm{~F}_{5}\right)_{3}{ }^{-}\right]$.

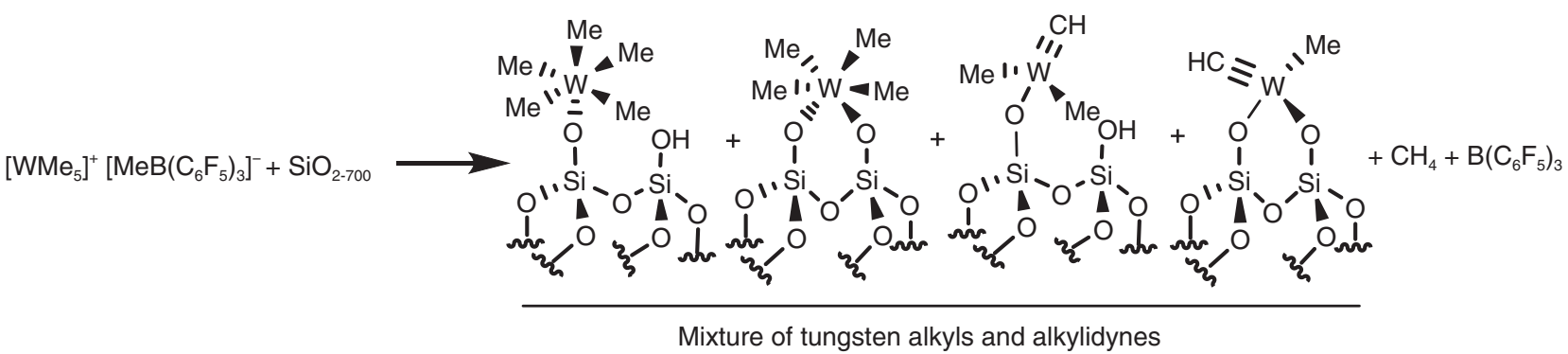

Scheme 3

Grafting of $\left[\mathrm{WMe}_{5}\right]^{+}\left[\mathrm{MeB}\left(\mathrm{C}_{6} \mathrm{~F}_{5}\right)_{3}{ }^{-}\right]$onto the silica ${ }_{700}$ support.

non-nucleophilic anion after de-methylation reaction. When the reaction was monitored by NMR at $-20^{\circ} \mathrm{C}$, it was found that the reaction between $\mathrm{WMe}_{6}$ and $\mathrm{B}\left(\mathrm{C}_{6} \mathrm{~F}_{5}\right)_{3}$ was very fast and the peak corresponding to $\mathrm{WMe}_{6}$ at $1.75 \mathrm{ppm}$ in ${ }^{1} \mathrm{H}-\mathrm{NMR}$ almost completely disappeared in less than 15 minutes and two new peaks at $2.68 \mathrm{ppm}$ and $0.48 \mathrm{ppm}$ were formed (Fig. 1). The product generated by the above reaction has a fair stability below $-40{ }^{\circ} \mathrm{C}$ in the absence of light. However, upon warming this reaction mixture to $0{ }^{\circ} \mathrm{C}$ from $-40{ }^{\circ} \mathrm{C}$, a very first decomposition of the cationic complex was observed with release of gaseous methane. Based on the above experimental facts, one can assume the two possibilities; where Path I (Scheme 2) is the formation of neutral tungsten complex by the ligand metathetical exchange and Path II (Scheme 2) is de-methylation from $\mathrm{WMe}_{6}$, formation of cationic tungsten complex.

The ${ }^{1} \mathrm{H}-\mathrm{NMR}$ chemical shift at $+0.5 \mathrm{ppm}$ corresponds to $\left[\mathrm{CH}_{3}-\mathrm{B}\left(\mathrm{C}_{6} \mathrm{~F}_{5}\right)_{3}\right]^{-}$which is well documented in the literature $[21,22]$ and as expected the resonance for the methyl proton of $\mathrm{WMe}_{6}$ at $1.75 \mathrm{ppm}$ is shifted downfield to $2.7 \mathrm{ppm}$, and ascribed to $\left[\mathrm{WMe}_{5}\right]^{+}$. Similarly the ${ }^{13} \mathrm{C}-\mathrm{NMR}$ spectra also clearly shows that the peak at 83 ppm of $\mathrm{WMe}_{6}$ is also completely replaced by two peaks at $10.8 \mathrm{ppm}$ $\left[\mathrm{CH}_{3}-\mathrm{B}\left(\mathrm{C}_{6} \mathrm{~F}_{5}\right)_{3}\right]^{-}$and $103.2 \mathrm{ppm}$ corresponding to $\left[\mathrm{W}\left(\mathrm{CH}_{3}\right)_{5}\right]^{+}$which is good agreement with the literature value reported for $\left[\mathrm{CH}_{3}-\mathrm{B}\left(\mathrm{C}_{6} \mathrm{~F}_{5}\right)_{3}\right]^{-}$(Fig. 1). We also found in the ${ }^{1} \mathrm{H}-{ }^{13} \mathrm{C}$ correlation spectra that the peak at $0.5 \mathrm{ppm}$ in ${ }^{1} \mathrm{H}-\mathrm{NMR}$ was correlating with the peak at $10.8 \mathrm{ppm}$ in ${ }^{13} \mathrm{C}-\mathrm{NMR}$ and the peak at $2.7 \mathrm{ppm}$ in ${ }^{1} \mathrm{H}-\mathrm{NMR}$ was correlating with the peak at $103.2 \mathrm{ppm}$ in ${ }^{13} \mathrm{C}$-NMR. These spectroscopic data strongly support the formation of $\left[\mathrm{WMe}_{5}\right]^{+}\left[\mathrm{MeB}\left(\mathrm{C}_{6} \mathrm{~F}_{5}\right)_{3}\right]^{-}$. In separate experiments, we synthesised ${ }^{13} \mathbf{C}$ label $\mathrm{W}\left(\mathbf{C}^{13} \mathrm{H}_{3}\right)_{6}$ and upon treatment with $\mathrm{B}\left(\mathrm{C}_{6} \mathrm{~F}_{5}\right)_{3}$ we have thus identified incorporation of the labeled methyl in the final $\left[\left(\mathbf{C}^{13} \mathrm{H}_{3}\right) \mathrm{B}\left(\mathrm{C}_{6} \mathrm{~F}_{5}\right)_{3}\right]^{-}$anion. The above experiment clearly indicates that in $\left[\mathrm{MeB}\left(\mathrm{C}_{6} \mathrm{~F}_{5}\right)_{3}\right]^{-}$, ' $\mathrm{CH}_{3}$ ' came from $\mathrm{WMe}_{6}$ and strongly supports Path II (Scheme 2).

We then tried to graft cationic complex on the surface of silica-700, in order to get a cationic tungsten catalyst onto the heterogeneous support. However, after several attempts we were unable to identify any well define heterogeneous cationic tungsten complex except a mixture of neutral tungsten-methyl complex (Scheme 3). 


\begin{tabular}{lcc} 
& $\begin{array}{c}\mathrm{WMe}_{5}{ }^{+} \mathrm{MeBARF}^{-} \\
\text {in absence of light } 12 \mathrm{~h}\end{array}$ \\
\hline Substrate & Product & Yield \\
2-octene & 7-tentradecene & $40 \%(\mathrm{E} / \mathrm{Z}=3 / 1)$ \\
Cyclooctene & Po reaction & ------ \\
\end{tabular}

Scheme 4

Metathesis of olefin by cationic tungsten-methyl complex. $\mathrm{BARF}^{-}=\mathrm{B}\left(\mathrm{C}_{6} \mathrm{~F}_{5}\right)_{3}$

Tungsten cationic complex was found to be very effective for the metathesis of 1-octene and ROMP (Ring Opening Metathesis Polymerization) for cyclooctene. Cyclooctene was polymerized to polyoctenamer by ROMP at even $-40{ }^{\circ} \mathrm{C}$ by this cationic tungsten complex. However, this complex was inactive for metathesis of trans 2-octene (Scheme 4). The detailed mechanism and the precise nature of the active catalytic species are still unknown for this catalytic system. However from the control experiment, we found that $\mathrm{WMe}_{6}$ does not metathetise cyclooctene nor 1octene. From the above experiments, we can assume that the formation of a tungsten carbene intermediate is more favoured when starting from the cationic complex rather than neutral $\mathrm{WMe}_{6}$. A very similar observation was reported by Kress and Osborn, where they showed that cationic complexes are more active towards olefin metathesis than the corresponding neutral complexes [14]. Based on this, we speculate that a tetra coordinated cationic $\left[\mathrm{WMe}_{3}\left(=\mathrm{CH}_{2}\right)\right]^{+}[-$ $\left.\mathrm{MeB}\left(\mathrm{C}_{6} \mathrm{~F}_{5}\right)_{3}\right]^{-}$intermediate is formed from $\left[\mathrm{WMe}_{5}\right]^{+}[\mathrm{MeB}$ $\left.\left(\mathrm{C}_{6} \mathrm{~F}_{5}\right)_{3}\right]^{-}$by $\alpha-\mathrm{H}$ transfer into neighbouring methyl groups. However, we have never seen any carbene intermediates by NMR during the decomposition of $\left[\mathrm{WMe}_{5}\right]^{+}\left[\mathrm{MeB}\left(\mathrm{C}_{6} \mathrm{~F}_{5}\right)_{3}\right]^{-}$ while the experiments were carried out inside the NMR instrument for long time.

\section{CONCLUSION}

In summary, we have developed a straight forward strategy for the synthesis of extremely unstable high oxidation state cationic tungsten(VI)-methyl complex in a precise way, starting from $\mathrm{WMe}_{6}$. We fully characterised this unstable ionic species by ${ }^{1} \mathrm{H}-\mathrm{NMR},{ }^{13} \mathrm{C}-\mathrm{NMR},{ }^{1} \mathrm{H}-{ }^{13} \mathrm{C}$ correlation, etc., and also, we showed that this cationic complex is reactive in olefin metathesis reaction. To the best of our knowledge, this is the first example of a well defined cationic tungsten complex. Further studies are in progress to assess the reactivity of this tungsten complex and its application in other catalysis.

\section{ACKNOWLEDGMENTS}

This work was supported by funds from King Abdullah University of Science and Technology. RD would like to acknowledge SABIC for his SABIC postdoctoral fellowship.

\section{REFERENCES}

1 Shortlan A., Wilkinson G. (1973) J. Chem. Soc. Dalton 8, 872-876.

2 Shortlan A., Wilkinson G. (1972) J. Chem. Soc. Chem. Comm. 6, 318 .

3 Galyer L., Mertis K., Wilkinson G. (1975) J. Organomet. Chem. 85, 37-38.

4 Galyer A.L., Wilkinson G. (1976) J. Chem. Soc. Dalton 21, 2235-2238.

5 Seppelt K. (1996) Science 272, 182-183.

6 Kleinhenz S., Pfennig V., Seppelt K. (1998) Chem.-Eur. J. 4, 1687-1691.

7 Seppelt K. (2003) Accounts Chem. Res. 36, 147-153.

8 Kaupp M. (1996) J. Am. Chem. Soc. 118, 3018-3024.

9 Demolliens A., Jean Y., Eisenstein O. (1986) Organometallics 5, 1457-1464.

10 Kang S.K., Albright T.A., Eisenstein O. (1989) Inorg. Chem. 28, 1611-1613.

11 Samantaray M.K., Callens E., Abou-Hamad E., Rossini A.J., Widdifield C.M., Dey R., Emsley L., Basset J.M. (2014) J. Am. Chem. Soc. 136, 1054-1061.

12 Callens E., Abou-Hamad E., Riache N., Basset J.M. (2014) Chem.Commun. 50, 3982-3985.

13 Samantaray M.K., Dey R., Abou-Hamad E., Hamieh A., Basset J.-M. (2015) Chem.-Eur. J. 21, 6100-6106.

14 Kress J., Osborn J.A. (1983) J. Am. Chem. Soc. 105, 6346-6347.

15 Schrock R.R., Hoveyda A.H. (2003) Angew. Chem. Int. Ed. 42, 4592-4633.

16 Ward B.D., Orde G., Clot E., Cowley A.R., Gade L.H., Mountford P. (2004) Organometallics 23, 4444-4461.

17 Cremer C., Burger P. (1999) J. Chem. Soc. Dalton Trans. 1967-1974.

18 Nakazawa H., Kishishita M., Miyoshi K. (1999) Phosphorus, Sulfur, and Silicon and the Related Elements 144, 45-48.

19 Eide E.F., Piers W.E., Parvez M., McDonald R. (2007) Inorg. Chem. 46, 14-21.

20 Schowner R., Frey W., Buchmeiser M.R. (2015) J. Am. Chem. Soc. 137, 6188-6191. 
21 Spitzmesser S.K., Gibson V.C. (2003) J. Organomet. Chem. 673, 95-101.

22 Gillis D.J., Tudoret M.-J., Baird M.C. (1993) J. Am. Chem. Soc. 115, 1993, 2543.
Manuscript submitted in September 2015

Manuscript accepted in January 2016

Published online in April 2016

Cite this article as: R. Dey, M.K. Samantaray, E. Callens, A. Hamieh, A.-H.M. Emwas, E. Abou-hamad, S. Kavitake and J.-M. Basset (2016). Cationic Tungsten(VI) Penta-Methyl Complex: Synthesis, Characterization and its Application in Olefin Metathesis Reaction, Oil Gas Sci. Technol 71, 21. 